Adventure Capital 
The publisher and the University of California Press Foundation gratefully acknowledge the generous support of the Ahmanson Foundation Endowment Fund in Humanities. 


\title{
Adventure Capital
}

Migration and the Making of an

African Hub in Paris

\author{
Julie Kleinman
}

阳

UNIVERSITY OF CALIFORNIA PRESS 
University of California Press, one of the most distinguished university presses in the United States, enriches lives around the world by advancing scholarship in the humanities, social sciences, and natural sciences. Its activities are supported by the UC Press Foundation and by philanthropic contributions from individuals and institutions. For more information, visit www.ucpress.edu.

University of California Press

Oakland, California

(c) 2019 by Julie Kleinman

Library of Congress Cataloging-in-Publication Data

Names: Kleinman, Julie, author.

Title: Adventure capital : migration and the making of an African hub in Paris / Julie Kleinman.

Description: Oakland, California : University of California Press, [2019] | Includes bibliographical references and index. |

Identifiers: LCCN 2019014743 (print) | LCCN 2019019829 (ebook) | ISBN 9780520304406 (cloth : alk. paper) | ISBN 9780520304413 (pbk. : alk. paper) | ISBN 9780520973084 (ebook)

Subjects: LCsH: West Africans-France-Paris. | Immigrants-FranceParis. | Gare du Nord (Paris, France). | Racism-Economic aspectsFrance-Paris.

Classification: LCC DC718.A34 (ebook) | LCC DC718.A34 K55 2019 (print) | DDC 944/.361004966-dc23

LC record available at https://lccn.loc.gov/2019014743

Manufactured in the United States of America

$\begin{array}{llllllllll}28 & 27 & 26 & 25 & 24 & 23 & 22 & 21 & 20 & 19\end{array}$

$\begin{array}{llllllllll}10 & 9 & 8 & 7 & 6 & 5 & 4 & 3 & 2 & 1\end{array}$ 
Dòw b’a fò olu ma "clandestin"

Anw dun ko olu ma tunkannaden

Some call them "illegals"

We call them children of adventure

-FATOUMATA DIAWARA, CLANDESTIN 
